\title{
MIR1246 wt Allele
}

National Cancer Institute

\section{Source}

National Cancer Institute. MIR1246 wt Allele. NCI Thesaurus. Code C157559.

Human MIR1246 wild-type allele is located in the vicinity of 2 q31.1 and is 73 bases in length. This allele, which encodes MIR1246 pre-miRNA, may be involved in the regulation of gene expression in various cancers. 